\title{
Spark, trauma and the novel
}

\author{
Article
}

Accepted Version

Cheyette, B. (2018) Spark, trauma and the novel. Textual Practice, 32 (9). pp. 1659-1676. ISSN 1470-1308 doi: https://doi.org/10.1080/0950236X.2018.1533172 Available at https://centaur.reading.ac.uk/77626/

It is advisable to refer to the publisher's version if you intend to cite from the work. See Guidance on citing.

To link to this article DOI: http://dx.doi.org/10.1080/0950236X.2018.1533172

Publisher: Taylor \& Francis

All outputs in CentAUR are protected by Intellectual Property Rights law, including copyright law. Copyright and IPR is retained by the creators or other copyright holders. Terms and conditions for use of this material are defined in the End User Agreement.

\section{www.reading.ac.uk/centaur}

\section{CentAUR}

Central Archive at the University of Reading

Reading's research outputs online 


\section{Bryan Cheyette}

\section{Spark, Trauma and the Novel}

Her sense of being written into the novel was painful.

(Muriel Spark, The Comforters) $^{1}$

It was in Africa that I learned to cope with life. It was there that I learned... to put in a peripheral place the personal sorrows, frights and horrors that came my way.

(Muriel Spark, Curriculum Vitae) $^{2}$

Am I a woman ... or an intellectual monster?

(Muriel Spark 'Bang, Bang, You're Dead') ${ }^{3}$

Muriel Spark gained a good deal from avant-garde movements such as the French nouveau roman of Alain Robbe-Grillet and the British 'experimentalism' of B. S. Johnson and Christine Brooke-Rose in the 1950s and 60s; the feminist writing of the 1970s; and post-modern and magical realist fiction of the 1980s and 1990s. At the same time, she has continued the long tradition of comedy of manners and literary satire in much of her work and has placed these more conventional modes alongside the avantgarde. What is clear from even a cursory reading of Spark's dazzling and cunning fictions is that she only ever engages with these various literary modes in so far as they can be subsumed by her singular vision. Spark's quirky and playful voice refuses to be contained by any one doctrine or identity. Her abiding doubleness, above all, places a sense of history, tradition and the avant-garde next to an irreverent and whimsical sense of the absurdity of all human philosophies and identities. First among the philosophies and identities which she finds absurd is that of the conventional realist novel with its humanist assumptions that the plot of a novel, with the individual at its heart, can be confused with life. ${ }^{4}$ 
Spark's fiction is full of solipsistic villains who are novelist-manqués and seek to manipulate the lives of others as if it were merely plot-making. These figures such as Jean Brodie in The Prime of Miss Jean Brodie (1961), Lister in Not to Disturb (1971), or Alexandra in The Abbess of Crewe (1974) are mythomaniacs who attempt to shape reality according to their obsessions. Spark's novels recognise that the plots of men and women (not least the blackmailers throughout her fiction) come to nothing when viewed sub specie aeternitatis. She realises, in stark contrast to her mythomaniacs, that the 'traditional form of the novel was itself complicit in a false and radically impoverished form of life'. ${ }^{5}$ Individuals cannot determine reality which is why the divine presence is so necessary. But there is always a twinkling irony in Spark's fiction, not least in her characteristic use of prolepsis, as the voice of the omniscient meta-narrator and God's plots are often indistinguishable.

That Spark has to 'leave' the world of her characters when assuming the voice of a god-like narrator alerts us once again to her abiding sense of the realist novel as nothing more than an all too human form of deception. But Spark's distrust of human story-telling is matched only by her confidence in incorporating her own life-story into the novel-form. After all, she famously justified her own mythic origins as a novelist to Frank Kermode as 'probably just a justification for the time I wasted doing something else'. She went on to say that her novels are an attempt to 'redeem the time' so that the years before The Comforters (1957), her first novel, 'won't be wasted - it won't be wasted until I'm dead'. ${ }^{6}$ Spark started writing fiction soon after she converted to Catholicism in 1954 although she had published some important stories and a significant body of poetry before her conversion. Both religious conversion and novel writing are a form of transfiguring waste which is why Spark's life was supposedly redeemed in 1954. Her first forty years, before she started writing novels, became the necessary 'waste' material for much of her subsequent fiction. Spark was to imaginatively re-invent her past selves and to reclaim 
her wilderness years for the artistic sphere as late as Loitering with Intent (1981) and A Far Cry from Kensington (1988). That is why she so distrusted those who represented her early years, myself included. ${ }^{7}$

The unavoidable exchange between life and art, as Spark conceived it, can be found in her early study of the poet John Masefield: 'those parts of his life story which the poet himself has written about never fail to give the impression that life has always presented itself to him, as it were, in the narrative form ${ }^{8} .{ }^{8}$ Spark's obsession with Emily Brontë equally results in a life that was always already narrated: 'What impressed me was the dramatic shape of her life. It's as if she had consciously laid out the plot of her life in a play called Emily Brontë'. ${ }^{9}$ Her account of Charlotte and Emily Brontë links their 'creative powers' with their refusal of 'orthodoxy' and their 'personal sufferings' ${ }^{10}$ This is also the story of Muriel Spark. With the publication of The Comforters Spark began to play with her own life-story as a 'narrative form'. As she states in Curriculum Vitae:

I didn't feel like 'a novelist' and before I could square it with my literary conscience to write a novel, I had to work out a novel-writing process peculiar to myself, and moreover, perform this act within the very novel I proposed to write. ${ }^{11}$

Spark could not 'feel' like a novelist until she had witnessed herself, from the outside, performing the act of writing a novel. But because this is a 'process peculiar to myself' Spark also needed to enact her new sense of self from the inside as well. This is why Caroline Rose, Spark's heroine, is oddly a character in a novel who writes about 'Characters in a novel'. ${ }^{12}$ She is also a version of Muriel Spark with 'her family on the Jewish side', her time spent 'in Africa', and her 'literary reputation'. ${ }^{13}$ This doubleness, both inside and outside, interested and disinterested, characterises Caroline's neurotically fractured self. Her hallucinations, after all, take the form of hearing voices created by a 'Typing Ghost' which self-consciously transforms her life into a narrative. ${ }^{14}$ Writing and 
madness - the narrative unification of a fragmented self - is intimately related in this book and in much of Spark's work culminating in The Driver's Seat (1970). For this reason, we are never quite sure in The Comforters of the status of Caroline's story within a story. Is she suffering from paranoid delusions (the victim of a diabolical 'plot') or groping towards divine mystery? This sense of being on the cusp of delusion and prophecy positions her, like so many of Spark's heroines, both inside and outside her own story:

Her sense of being written into the novel was painful. Of her constant influence on its course she remained unaware and now she was impatient for the story to come to an end, knowing the narrative would never become coherent to her until she was at last outside it, and at the same time consummately inside it. ${ }^{15}$

From the beginning Spark was concerned about the kind of stories she could use to turn life into art ('Her sense of being written into the novel was painful'). She also wanted to be in control of the stories which she tells ('of her constant influence on its course she remained unaware'). That is why her early novels are invariably on the lookout for selfdeluded story-tellers, dangerous mythomaniacs, and insidious poetasters in a bid to make the difference between good and bad writing an ethical consideration - part of the 'Providence of God'16 — as well as a form of aesthetic ordering. Caroline, after all, needs a sense of detachment (viewing herself from the 'outside') to enable her sense of self to cohere. But she also needs to defeat crass manipulators such as Georgina Hogg, and to write about this experience, so that it can become the plot of The Comforters. Most critics have noted Spark's simultaneous conversion to both Roman Catholicism and the art of the novel and have argued mistakenly that these coexisting transformations are somehow equivalent. These differing acts of conversion are mirror-images of each other but that 
does not mean that there is an organic coherence between religion and art, ethics and aesthetics. ${ }^{17}$

Spark's late writing, which I will focus on, makes the clearest distinctions between aesthetic conversion - turning life into art or narrative- and religious conversion. One form of conversion is on the side of an unresolved doubleness, the other on the side of unification. Far from merely unifying old and new, past and present, aesthetic conversion is an interpretative act which perceives one world through the eyes of another. ${ }^{18}$ Spark's fiction reinterprets the secular novel as a parodic form of spiritual transfiguration, while her Catholicism is observed with an artist's sceptical eye. In this light, it is a mistake just to focus on Spark's proleptic narrator as a Joycean 'Catholic novelist of detachment'. ${ }^{19}$ As I argue in my longer work, Spark eventually questioned the redemptive values of clarity and order which were so necessary to her in the 1940s and 50s. She was all too aware of the difficulties of redeeming the world in her fiction however much her God-like narrators might want to. ${ }^{20}$ Those parts of her past which she wished to transfigure invariably proved to be uncontainable and returned to haunt her. The suffering which Spark experienced during her 'wasted years'-such as her husband's violent nervous disorder in Southern Africa or her poverty and 'breakdown'21 in London in the 1940s and 50s - often eluded a redemptive narrative. Madness, singularity and unrestrained emotion are the stuff that cannot be converted easily into an untroubled and impersonal story which is why she continually drew on these experiences in her fiction.

The particular trauma, which Spark put in a 'peripheral place', can be found in her African stories collected in The Go-Away Bird and Other Stories (1960) and Voices at Play: Stories and Ear-Pieces (1961). ${ }^{22}$ At the age of 19, Muriel Camberg left Edinburgh for Southern Rhodesia (now Zimbabwe) to marry her husband, Sydney Oswald Spark 
('SOS'). Written from the perspective of the victims of violence, many of the stories of her time in Southern Africa (1937-44) concern the commonplace murder of white women. In 'Bang-Bang You're Dead' (1961) a friend of Spark's narrative persona is accidentally shot as they resemble each other. The fear of being shot pervades the story:

There had been an outbreak of popular headlines about the shooting affairs in the Colony. Much had been blared forth about the effect, on the minds of young settlers, of the climate, the hard drinking, the shortage of white women. The Colony was a place where lovers shot husbands, or shot themselves, where husbands shot natives who spied through bedroom windows. ${ }^{23}$

The 'climate' of Africa causes various kinds of neuroses ('on the minds of young settlers') which can take a violent form. These 'shooting affairs' are repeated in Spark's African stories and radio dramas, such as 'The Curtain Blown by the Breeze' (1954), where a husband shoots a 'native' who 'spied through bedroom windows' and The Dry River Bed (1961) which concerns the slaying of two white women. These 'shooting affairs' are also recounted in Curriculum Vitae in a reprise of the plot of 'Bang-Bang You're Dead':

When Nita McEwan, a friend from school, was killed that night by her husband in the hotel [in Rhodesia] where I was staying, I got seriously frightened. My husband had a small revolver, a 'baby Browning', which he liked to fire off in corridors and courtyards. I hid it and refused to hand it over when he demanded it. $^{24}$

Here Spark identifies with her characters who are victims of these 'shooting affairs' and associates them with her husband's violent disorder: 'I knew my married life was over'. ${ }^{25}$ 
Her poem 'Like Africa' (1948), written after she returned to London, also elides her experience in Africa with a deranged form of masculinity:

He is like Africa and even

The dangerous chances of his mind

Resemble the precipice whereover

Perpetual waterfalls descend. ${ }^{26}$

That the African landscape embodies male insanity is also seen in 'The Curtain Blown by the Breeze' where 'the curtain was fluttering at the open window, letting in wafts of the savage territory beyond the absurd drawing-room'. ${ }^{27}$ The 'savage territory' transforms men into beasts.

It was in Bulawayo in 1938, part of this 'savage territory', that Spark's son, Samuel Robin, was born after her short-lived marriage. In 1944 she returned to England in a troop ship after divorcing her husband who had custody over their son. ${ }^{28}$ The young boy was left in a convent school in Southern Africa until the war was over and he was subsequently raised in Edinburgh by Spark's parents. After these early stories and poems, Spark did not write about Africa again until Aiding and Abetting: A Novel (2000) although there are references to Africa in a few novels. ${ }^{29}$

\section{II}

Writing novels enabled Spark to absorb those traumatic aspects of her life-story and make them 'peripheral'. ${ }^{30}$ This strategy is first articulated in her literary manifesto 'The Desegregation of Art' (1971) which is an extended refutation of past suffering. Her manifesto was written at the end of a period of extraordinary creativity, which saw the publication of The Public Image, The Driver's Seat and Not to Disturb from 1968 to 1971. It is not a coincidence that these three novellas were the closest that Spark came to 
the French nouveau roman and, as a result, were the least messy, the least emotionally invested, of her fictions. ${ }^{31}$ These novellas signalled a distinct shift from actuality to artifice, from the past to the present, and to a pitiless tone which was described by Angus Wilson, in relation to her earlier fiction, as 'machine made'. ${ }^{32}$ Spark was quite explicit in her manifesto about reinforcing a novel form where the author was at her most imperious and could compose her characters sub specie aeternitatis. After living in New York in the early 1960s, Spark moved to Rome in $1966 .{ }^{33}$ She could now champion the cold eye of the permanent exile:

...the art and literature of sentiment and emotion, however beautiful in itself, however striking in its depiction of actuality, has to go. It cheats us into a sense of involvement with life and society, but in reality it is a segregated activity. In its place I advocate the arts of satire and of ridicule. And I see no other living art form for the future. ${ }^{34}$

According to Spark, the prevailing 'cult of the victim' was at the heart of the 'literature of sentiment and emotion' and resulted in a banal emotional catharsis disconnected from 'life and society'. ${ }^{35}$ But this was an extraordinary statement to make in the United States in the 1970s. As Martin Stannard notes, 'the Vietnam conflict was raging, anti-war demonstrations and race riots [were] tearing American cities apart' and, as a result, there was a heightened sense at the time of who the victims of racism and slavery were. ${ }^{36}$ What is more, terms like 'segregation' and 'desegregation' in the United States were far removed from Spark's championing of the 'arts of satire and ridicule'.

By refusing to reduce her concerns to the sphere of suffering and victimization, 'The Desegregation of Art' imposed Spark's rather idiosyncratic preoccupations onto the racial politics of the United States. In a 1970 interview, repeated in The Hothouse by the East River (1973), Spark stated that she does not 'believe in good and evil so much 
anymore' but in 'absurdity and intelligence'. ${ }^{37}$ Perhaps for this reason Spark edited out any references in The Hothouse by the East River to what she calls, in an earlier version, 'the draft riots in the Civil War when black men were hung from the lamp posts'. ${ }^{38}$ These reconstructions of 'gross racial injustices'39 in The Hothouse by the East River were originally intended to follow The Mandelbaum Gate (1965) which included an account of the Eichmann trial. Spark's use of the nouveau roman was a direct response to her prolonged exploration of the past, especially her uncertain Jewishness, in this rather baggy novel. By the time of 'The Desegregation of Art', Spark was no longer interested in the life-story of the individual (herself included) or in the virtues of historical reconstruction. Only 'absurdity and intelligence' was 'illuminating' even in relation to the rise of Nazism:

We have all seen on the television those documentaries of the thirties and of the Second World War, where Hitler and his goose-stepping troops advance in their course of liberating, as they called it, some country or other; we have seen the strutting and posturing of Mussolini. It looks like something out of comic opera to us. If the massed populations of those countries had been moved to break up in helpless laughter at the sight, those tyrants wouldn't have had a chance. And I say we should all be conditioned and educated to regard violence in any form as something to be ruthlessly mocked..$^{40}$

Spark worked as a 'black propagandist' in the last year of the Second World War where she helped to present a subversive version of the war to the German people via a fake German radio station. 'The Desegregation of Art', which was first given as a lecture to the Blashfield Foundation in New York, seems to follow this activity and assumes that the populations of Germany and Italy could potentially have been 'moved' by the mocking intelligence of such black propaganda. But the idea of coaxing the populations 
of Italy and Germany into 'helpless laughter' at the sight of Hitler and Mussolini is, to put it mildly, a utopian version of this wartime activity. ${ }^{41}$ 'The Desegregation of Art' championed the redemptive powers of art over historical suffering which was to harden into a form of Sparkian orthodoxy. But this orthodoxy meant that the 'only problem' after the Second World War, the problem of suffering, was incorporated into the travails of the novelist. ${ }^{42}$ In short, Spark championed satire so as to ensure that her 'ghastly objects of investigation no longer [had] the capacity to hurt' which was the implicit message of 'The Desegregation of Art' ${ }^{43}$

The redemptive power of absurdity and intelligence was also to become an originary myth in Spark's life-story 'The First Year of My Life' (1967) which elided the date of her birth with the birth of the artist. In this part autobiographical, part apocryphal, story Spark presents the First World War through the eyes of a new-born child as 'babies, in their waking hours, know everything that is going on everywhere in the world' ${ }^{44}$ These supernatural powers of perception, a kind of innocent omniscience akin to the omniscience of the Sparkian narrator, are supposedly 'brainwashed out of us' after our first year. ${ }^{45}$ Like Spark, who also came into a blood-ridden world in 1918, the baby 'had been born into a bad moment in the history of the world' and is rendered glum looking as it witnesses 'infinite slaughter' ${ }^{46}$ Only after a fatuous speech by Herbert Asquith in the House of Commons, about the 'cleansing and purging' effects of the war, does the baby smile. ${ }^{47}$ It is typical of Spark that she compares a false form of purgation with the power of humour to redeem even the slaughter of the First World War. Here the omniscient, allknowing baby is not unlike the impersonal artist (pace T. S. Eliot) who is also a conduit for a series of voices from the fallen world of the twentieth-century. ${ }^{48}$

The fraught relationship between suffering and rebirth, in the form of both irredeemable trauma and redemptive comedy, is always in tension with the much less binary, rather more anarchic, fictions of Spark. After 'The Desegregation of Art', Spark 
wished to declare the power of the artist to control and expunge suffering which she had experienced first-hand and which characterised her 'wasted years'. That Spark settled on a particular voice and style to counter the politics of victimhood is, however, only one part of the story. To gain the level of detachment from both personal and historical suffering, which is most apparent in Spark's version of the nouveau roman, meant that she had to treat a part of herself 'as though she were dead' ${ }^{49}$ It is the haunting distance from a 'dead' version of the self which, according to Stannard, 'generated her pleasure in the world, beat back its terrors' ${ }^{50}$ But the one part of her that could not be dispatched, or completely redeemed, was that which was so traumatised that it was strangely absent (or 'peripheral') throughout half a century of writing fiction. 'The Seraph and the Zambesi' (1951), her prize-winning story, made it possible for Spark to become a novelist but the trauma of Africa was soon buried deep within her psyche.

\section{III}

By the 1990s, the moments of irredeemable horror which are sprinkled throughout most of Spark's books, and often take the form of a dead or mutilated female body, could no longer be contained. Her late fiction 'drips with blood', according to the first pages of Symposium (1990) and Reality and Dreams (1996), or, more analytically in Aiding and Abetting, is preoccupied with the 'facts of blood'. ${ }^{51}$ This latter novel, which I will focus on, returns the reader to many of Spark's formative preoccupations such as the murderous husbands of her African stories and the countervailing scepticism of her Gentile-Jewish heroines in The Comforters, 'The Gentile Jewesses' and The Mandelbaum Gate. ${ }^{52}$ Aiding and Abetting is both a summation of these earlier concerns and a brazen refutation of the novel in favour of other kinds of stories. That Lucan is the culmination of Spark's bad novelists (in all senses) redoubles an already sensational story that has been told elsewhere. As Spark writes rather defensively in her Note to Readers: 
The following story, like all those connected with the seventh Earl of Lucan is based on hypothesis.

The seventh Earl has been missing since... his wife was taken to hospital severely wounded in her head, and the body of his children's nanny was found battered, in a mailsack, in his house.

...What we know about 'Lucky' Lucan, his words, his habits, his attitudes to people... I have absorbed creatively, and have metamorphosed into what I have written. ${ }^{53}$

Spark moves from a factual hypothesis to creative metamorphosis all in the name of a story that has been told many times before in a variety of forms. No wonder everything in Aiding and Abetting is doubled and redoubled and her work of fiction, in case we dare to think otherwise, is subtitled 'A Novel'. ${ }^{54}$ The book begins sensationally with the figure of Lord Lucan visiting a psychiatrist, Dr Hildegard Wolf, in her Parisian offices. While this is startling in itself - the actual Lord Lucan is thought to have died in Africa some years ago - it is compounded by the bizarre fact that Hildegard Wolf already has a 'Lord Lucan' as a patient. What is more, it turns out that Hildegard was once known as Beate Pappenheim and has a wholly other history.

Hildegard is an exemplary exilic heroine -she originally came from 'Bavaria, then Prague, Dresden, Avila, Marseilles, then London, and [is] now settled in Paris ${ }^{95}$ — and is not unlike Spark's earlier radically divided Gentile-Jewesses such as Caroline Rose in The Comforters or Barbara Vaughan in the Mandelbaum Gate. Born Beate Pappenheim on a pig farm near Nuremberg, she managed to escape extreme poverty by becoming a 'fake stigmatic' who tricked thousands of impoverished Catholics into sending her 'many millions of marks'. ${ }^{56}$ After changing her identity she became Dr Hildegard Wolf, a celebrated psychiatrist practising in the centre of Paris. It is no coincidence that her 
original name is literally a beatification of Bertha Pappenheim, Freud's 'Anna O', one of his most famous patients. As is well known, Bertha Pappenheim appears in Joseph Breuer's and Sigmund Freud's Studies in Hysteria (1895) and subsequently became the first social worker in Frankfurt-am-Main and was the founder of the German-Jewish feminist movement. ${ }^{57}$ But, as Beate is born in a pig farm near Nuremberg, she could not be further removed from the biography of Bertha Pappenheim. At the same time, Beate and Bertha are brought together in relation to the scientific pretensions of psychoanalysis which, not unlike an orthodox Catholic conversion narrative, is supposedly meant to be able to cure the diseased and unhealthy (or 'hysterical') mind.

As with the two Lord Lucans, Hildegard's dual self is said by Spark to be 'based on fact ${ }^{9}{ }^{58}$ What is more, like at least one of the Lord Lucans, one of the Hildegards exists elsewhere in another story written by Breuer and Freud. But it is to Spark's great credit that such an absurd narrative is strangely plausible. Both Lucan and Hildegard are bogus, and each know that they are bogus, which is why they are uncanny mirror-images of each other. Although Spark is at pains to differentiate her two main characters (as one has taken a life), together they make a compelling narrative. They are both fugitives from the law, who have been on the run for most of their lives, and both have been forced to assume alternative identities (Spark's Lucan undergoes plastic surgery). Beate Pappenheim's blood ritual, in particular, is dramatically related to Lucan's murder victim, Sandra Rivett, whose blood 'got everywhere. Pools of it'. ${ }^{59}$ Beate, the holy stigmatic, copied one of the five wounds of Christ by covering herself in menstrual blood so that it would seep through her bandaged hands, feet or sides. These spurious 'wounds' were a sign of her 'healing powers' which, in a typical Sparkian paradox, actually helped her perform minor 'miracles'. ${ }^{60}$ This interest in 'voodoo' and in 'blood cults' relates her to 'witch men' in central Africa whose similar use of 'fraudulent mystifications', according to Karl Kanzia Jacobs, could also have a curative effect. ${ }^{61}$ 
After the murder, Lucan was 'so covered in blood' that bloodstains appeared on his clothes and letters sent to friends. ${ }^{62}$ By the end of Aiding and Abetting, in fact, Lucan makes the blood-connection explicit between himself and Hildegard — 'we're both in this blood-business together, he seemed to say' ${ }^{63}$ — although it is precisely these superficial similarities which are countered throughout the book. Hildegard and Lucan are both selfmythologisers, with links to Africa, and both are in the 'blood business'. But these stories are not the same. The therapeutic 'Wolf method' allows Hildegard's voice to overwhelm her patients, with God-like narrative authority, for the first three sessions. ${ }^{64}$ Lucan, in stark contrast, is shown to be a bad writer in both aesthetic and moral terms as he believes that it is his 'destiny' to kill his wife. As a result of this mistaken belief, he constructs a story-line to make her murder look like the result of a robbery:

[Lucan] had thought his plan to kill his wife was watertight. Whereas, even if the nanny had taken her night off, even if he had murdered the countess, the plot leaked at every seam as truly as did the blood-oozing mailbag into which the body of Sandra Rivett was packed. ${ }^{65}$

The sensational conflation of metaphor and reality at the end of this statement - which brings together the leaky plot of an ill-thought out novel and a 'blood-oozing mailbag'shows just how dangerous bad novels can be. In her short story, 'The Fortune-Teller' (1985), Spark distinguishes crucially between having a 'destiny' and a 'destination' which is also the plot of The Driver's Seat. ${ }^{66}$ Once a life-story is thought of as a foregone conclusion, determined by a single destiny, then other possible destinations are of necessity excluded and diminished. It is Lucan's sense of 'destiny' that makes him the last of Spark's evil writer manqués who attempt to shape the world according to their own insane obsessions: 'Lucan believed in destiny. By virtue of destiny he was an earl. His wife had been destined to die, according to his mad calculation. His "needs" dictated fate 
itself' ${ }^{67}$ His lack of 'imagination', which prevented him from imagining other possible destinations, relates him to Spark's version of Adolf Eichmann in The Mandelbaum Gate. ${ }^{68}$ While Hildegard, a version of the Gentile Jewess, is open to a myriad of different voices and destinations, Lucan only has a single sense of destiny which is reduced ultimately to a bad fiction where his wife, among others, is 'destined to die'.

The exuberance of Aiding and Abetting is in stark contrast to its blood-ridden subject-matter. In this late novel, the 'facts of blood' are not reduced to mere biology or racial determinism but are given a gloriously expansive set of meanings. As Hildegard's lover says of her past spoof activities: 'I don't blame her for doing something constructive with her own blood. What else should a woman of imagination do with her menstrual blood?'. ${ }^{69}$ While Hildegard's redemptive imagination is able to transform her personal circumstances, as well as the most mundane biological functions, Lucan, utterly devoid of imagination, fails to abolish the 'blood' and 'mess' which he had unleashed in 1974.

What brings Lucan and Hildegard together is their mutual fear of the past with Hildegard noting from the beginning that: 'I am being threatened... about some past life of mine, something in another world. It's upsetting me. Not rationally, of course. But I don't know quite what to do'. ${ }^{70}$ Both are troubled by the 'memories of the past' and both have a 'blood secret' which they attempt to expunge. ${ }^{71}$ Once again, Spark is preoccupied with those irredeemable traumatic aspects of her characters' past lives which haunt the present. At the same time, the novel's stress on the continual remaking of identity is clearly an implicit riposte to those, such as her son Samuel Robin, who believe that one is merely determined by the past and cannot reinvent the self. ${ }^{72}$

After they erase their personal histories, Spark seems to be arguing that the newfound identities of Hildegard and Lucan have a performative quality which is able to transcend the most rigid forms of determinism. To be sure, Hildegard is at pains to distinguish between the real and false Lucans in moral terms - after all one is a 
murderer-but she can still argue of the Lucan impostor that: 'after twenty-five years of playing the part of the missing Lord Lucan he surely is the part'. ${ }^{73}$ In a bid to avoid penury, thanks to the intervention of Karl Jacobs, both Lucan and his double migrate to Kanzia to tutor the children of Chief Kanzia. The Chief argues that his many children will benefit from consuming one of the Lucans - as 'we become in some measure what we eat ${ }^{74}$ — and, while preferring the innocent Lucan double, they mistakenly devour the real Lord Lucan. This glorious parody of the transubstantiation results in Chief Kanzia's children being turned in part into 'little Lord Lucans'. ${ }^{75}$ Rather than a single act of sacramental redemption, Spark ends with an extraordinarily charged moment of comic playfulness and plurality.

The 'facts of blood' are finally thrown into disarray in the last chapter of Aiding and Abetting with the tribe of Chief Kanzia, in a delightful instance of colonial mimicry, transformed bodily into members of the English aristocracy. Lucan's implacable sense of destiny is replaced by any number of possible racial destinations. But this is Spark's fiction at its most pleasurable where the reader has to work out the ambiguities of such risk-taking on the part of the author. On the one hand, the myriad of African Lord Lucans is a typical instance of Sparkian poetic justice (Lucan finally gets his comeuppance). Such game-playing also recalls the parodies of fundamental Catholic tenets which was an aspect of Spark's writing since 'Bang-Bang You're Dead' contained a pastiche of the resurrection. ${ }^{76}$ But the association of cannibalism with either Catholic ritual or African tribalism is, to say the least, a combustible issue. Aiding and Abetting is thus both dangerously anarchic as well as straightforwardly moralistic - in distinguishing, say, between the blood of Christ (the Blood of the Lamb) and Lord Lucan's daily diet of lamb chops.

When looked at from an African perspective, the story of Lord Lucan is a refiguring of the 'shooting affairs' in Spark's early African stories. But it is characteristic 
of Spark that she is, more than a half a century later, able to redeem the site of this abiding trauma by transforming it into the most subversive and playful element of her novel. By returning to the continent of Africa, deep within her past, Spark denies the 'facts of blood' in the spirit of Barbara Vaughan in The Mandelbaum Gate who compared the intransigence of blood with the fluidity of memory: 'memory circulates like the bloodstream. May mine circulate well, may it bring dead facts to life, may it bring health to whatever is to be borne. ${ }^{77}$ Spark's redemptive fiction is able to make a systematic murderer, devoid of imagination, part of the landscape of Africa. Aiding and Abetting could not have taken Spark further from an identity based on victimhood. The preoccupation with 'gentile Jewishness', as late as her penultimate novel, illustrates perfectly the power of a living memory over the 'dead facts' of blood.

\section{IV}

A year before Spark wrote Aiding and Abetting she was involved in a bitter public dispute with her son, Robin, concerning their 'racial origins' (as it was called). This dispute had been simmering since the 1980s and their differences were obviously a product of Robin being raised in Spark's uncomplicatedly Jewish Edinburgh home (at least in Robin's lifetime). ${ }^{78}$ In contrast to his mother's 'gentile Jewishness' her son was a self-described 'full Jew' who was part of the Edinburgh Hebrew Congregation. He insisted on a Bar Mitzvah (which Spark helped to pay for) and on an uncomplicated Jewish upbringing with Spark's parents acting in loco parentis. Family gravestones were Judaized much to Spark's and her brother's irritation. ${ }^{79}$ In effect, Robin converted (symbolically at least) to Judaism mirroring his mother's conversion to Catholicism. No wonder Aiding and Abetting is on the side of performative identities and against any form of hereditary determinism imposed by others. 
Published at the same time as Aiding and Abetting, Spark's story 'A Hundred and Eleven Years Without a Chauffeur' (2000) acted as a postscript. The narrator in the story refers to her Lithuanian Jewish and non-Jewish ancestors: 'I see no reason to drool over them. They did not drool over us' ${ }^{80}$ A photograph album depicting the various relations of Spark's narrator (who needs to produce photographs for her biographer) turns out to be a forgery. Spark ends the story with the following: 'I love these fake pictures, all of them' ${ }^{\prime 81}$ especially as one posthumously fulfils her mother's life-long desire to be chauffeur-driven. Fakery, once again, triumphs over genealogy. In a related story, 'The Young Man who Discovered the Secret of Life' (1999), Spark's opinionated narrator argues that the "lives of people hold many secrets...There was possibly no one "secret" applying to us all'. ${ }^{82}$ Rather than an all-explaining 'secret of life', Spark points to the 'many secrets' which make up her characters' lives. As always with Spark's fiction, made explicit in Aiding and Abetting, she is on the side of many possible secrets rather than a single 'blood secret' ${ }^{83}$

In the public dispute with her son in the first half of 1998, an all-determining 'DNA test' was called for to confirm (or not) Spark's 'secret' Jewishness. The call for a 'DNA test' was repeated in most accounts of the affair, especially in The Scotsman. In this newspaper, Spark's vow to scientifically 'prove [her] ethnic origin' was discussed in all seriousness by distinguished geneticists who argued at length that Jews who migrated from Eastern Europe would have a similar genetic make-up and could therefore be distinguished unequivocally from their non-Jewish counterparts. ${ }^{84}$ The deadening newspaper headlines_- 'Will the Real Muriel Spark Stand Up?'; 'Spark and Son in Feud over Jewish Origins'; 'Spark Vows to Prove Ethnic Origin' - could not be more reductive and were soon redeemed and refuted in Spark's fiction. ${ }^{85}$ 
It turned out that I was the unwitting catalyst for the heightened dispute between mother and son. At the beginning of 1998, I agreed to speak to the Edinburgh Jewish Literary Society on Spark's self-styled 'gentile Jewishness'. My audience, however, echoing Samuel Robin's position, insisted that Spark was fully Jewish and this quickly reached the newspapers. Robin was a member of the traditional congregation in Edinburgh and possessed a copy of his grandparents' ketubah (or orthodox Jewish wedding certificate). His grandmother, despite what Spark believed about her mother, must have been Jewish to obtain the certificate which removed any equivocation ('gentile Jewess') from her identity. Spark, instead, insisted on the memory of her home made up of many religions which was a key feature of her autobiographical story, 'The Gentile Jewesses' (1965). She also dismissed her son as playing the victim ('if he wants to be a victim, he can be a victim') in his insistence on an unambiguous Jewish identity. ${ }^{86}$ There was no greater insult from someone who had spent most of her life refusing victimhood. Such a fundamental refusal, a refusal to be determined by the past, was first signalled when Caroline Rose, in Spark's debut novel, vowed to end her own 'rapacity for suffering' ${ }^{87}$

After the talk in Edinburgh, my critical study of Spark's life and work (anticipating the eventual hostile response to Martin Stannard's biography) was immediately under threat. Stannard, ironically, was informed that if this 'unknown' (Cheyette) should 'slander her' (Spark) she was 'ready to sue'. ${ }^{88}$ Such a threat quickly materialized. Martin McQuillan, the editor of a new collection on Spark, to which I had contributed, sent her my unpublished chapter without my knowledge. In a long exchange between McQuillan and Spark, the chapter was interpreted in great detail by McQuillan which only increased her irritation and my incredulity. A slew of letters and faxes materialized from Spark's home in Arezzo. I was soon transformed into one of her evil writer manqués- a 'pisseur de copie' like Hector Bartlett in A Far Cry from Kensington - who was to be regally tossed aside. ${ }^{89}$ The version of Spark in my work was 
now, like so many versions before and after, suspect. Rather than publishing my book, not upsetting Dame Muriel became the watchword and hitherto liberal and open-minded academics became less liberal and less open-minded. Had Cheyette libelled his subject? What is all of this nonsense about Spark converting from a Jewish background? Spark had no such upbringing. This is what it felt like to be on the wrong side of Spark's fiction.

The cost of Spark's desire to redeem the 'waste' of her early life resulted in a peculiar orthodoxy. As she puts it in Curriculum Vitae: 'So many strange and erroneous accounts of parts of my life have been written... that I felt it time to put the record straight'. ${ }^{90}$ Curriculum Vitae in its rather lifeless, dull tone, on the side of unequivocal facts, stands in sharp distinction to her exuberant fiction. To be sure, Spark does evoke facticity in a novel as surreal and as outlandish as Aiding and Abetting. But the factual 'record' is only ever one side of the story in her fiction. The other side of facticity is those traumatic memories, pushed to the 'periphery', which were, of necessity, transformed into fiction. Her defence of this haunting world of 'waste' material is absolute. Any other account is dismissed out of hand. ${ }^{91}$ But such is the doubleness of Spark who was equally anarchic and orthodox; playful and controlling. In the end, her dismissal of the humancentred realist novel, and the fantasy that individuals can control the world, is both her strength and her weakness. It is her great strength as an artist -who views the world sub specie aeternitatis - but such anti-humanism, in the name of the divine, can also turn the writer into an 'intellectual monster'.92

\section{NOTES}

With many thanks to Vassiliki Kolocotroni and Willy Maley who are exemplary editors. I have also learned a great deal from my Sparkian friends and colleagues, Robert Eaglestone, Gabriel Josipovici, Andrew Nash, Marilyn Reizbaum and Nadia Valman. 
${ }^{1}$ Muriel Spark, The Comforters (London: Macmillan, 1957), p. 181.

${ }^{2}$ Muriel Spark, Curriculum Vitae: A Volume of Autobiography (London: Constable, 1992), p. 119

${ }^{3}$ Muriel Spark, 'Bang, Bang, You're Dead' in The Collected Stories (London and New York: Penguin Books, 1994), p. 85.

${ }^{4}$ For a version of this argument see Gabriel Josipovici, 'Muriel Spark and the Practice of Deception' in The Teller and the Tale: Essays 1990-2015 (Manchester: Carcanet Press, 2016), pp. 215-231. See also David Herman (ed.), Muriel Spark: Twenty-First Century Perspectives (Baltimore: The Johns Hopkins University Press, 2010).

5 Josipovici, 'Muriel Spark and the Practice of Deception', p. 226.

${ }^{6}$ Frank Kermode, 'The House of Fiction: Interviews with Seven Novelists', in Malcolm Bradbury (ed.), The Novel Today: Contemporary Writers on Modern Fiction (London: Fontana, 1977), p. 132.

${ }^{7}$ For the inevitable but resistant biographical readings in Spark's fiction see David Goldie, 'Muriel Spark and the Problems of Biography' in Michael Gardner and Willy Maley (eds), The Edinburgh Companion to Muriel Spark (Edinburgh: Edinburgh University Press, 2010), pp. 5-15. See also Bryan Cheyette, 'Was Muriel Spark Jewish?', TLS (January 31, 2018), https://www.the-tls.co.uk/articles/public/the-jewishness-ofmuriel-spark/ accessed June 15, 2018.

${ }^{8}$ Muriel Spark, John Masefield (London: Peter Nevill, 1953), p. x.

${ }^{9}$ Muriel Spark, Emily Brontë: Her Life and Work (London: Peter Owen, 1960), p. 314.

${ }^{10}$ Muriel Spark (ed.), The Brontë Letters (London: Peter Nevill, 1954), p. 16 and p. 21.

${ }^{11}$ Spark, Curriculum Vitae, p. 206.

${ }^{12}$ Spark, The Comforters, p. 202.

${ }^{13}$ Spark, The Comforters, pp. 38, 48, 67. 
${ }^{14}$ Spark, The Comforters, p. 161.

${ }^{15}$ Spark, The Comforters, p. 181. This quotation prefigures the method and conceit of The Driver's Seat (1970) where the inexorable ending quite literally drives the narrative. See also Peter Brooks's Reading for the Plot: Design and Intention in Narrative (New York: Alfred A. Knopf, 1984), chapter four.

${ }^{16}$ Muriel Spark, Memento Mori (London: Macmillan, 1959), p. 188.

17 This view was writ large in Ruth Whittaker, The Faith and Fiction of Muriel Spark (London: Macmillan, 1982), Peter Kemp, Muriel Spark: Novelists and Their World (London: Paul Elek, 1974), and David Lodge, The Novelist at the Crossroads and Other Essays on Fiction and Criticism (London: Routledge, 1971), chapter six. For a critique of this widespread assumption see Bryan Cheyette, Muriel Spark: Writers and Their Work (Plymouth: Northcote House Press, 2000).

18 This argument is influenced by Gauri Viswanathan, Outside the Fold: Conversion, Modernity, and Belief (New Jersey: Princeton University Press, 1998).

${ }^{19}$ For this orthodoxy see Malcolm Bradbury, 'Muriel Spark's Fingernails' in No, Not Bloomsbury (London: Arena, 1987), p. 271 and pp. 268-78.

${ }^{20}$ Cheyette, Muriel Spark, chapters one and seven.

${ }^{21}$ Muriel Spark, 'My Conversion', The Twentieth Century (Autumn, 1961), p. 60.

${ }^{22}$ Spark, Curriculum Vitae, p. 119. See also Abdel-Moneim Aly, 'The Theme of Exile in The African Short Stories of Muriel Spark', Scottish Studies Review 2.2 (2001), pp. 94104 and Eleanor Byrne, 'Muriel Spark Shot in Africa', in Martin McQuillan (ed.), Theorizing Muriel Spark: Gender, Race, Deconstruction (London and New York: Palgrave, 2002), chapter six.

${ }^{23}$ Spark, 'Bang, Bang, You're Dead', p. 64.

${ }^{24}$ Spark, Curriculum Vitae, p. 130. 
${ }^{25}$ Spark, Curriculum Vitae, p. 128. Byrne, 'Muriel Spark Shot in Africa', explores the interchange between Spark's memoir and fiction.

26 'He is Like Africa', New English Weekly (1948); reprinted in Roy MacNab (ed.), Towards the Sun: A Miscellany of Southern Africa (London: Collins, 1950), p. 80; reprinted as 'Like Africa', in Muriel Spark, All the Poems (Manchester: Carcanet, 2004), p. 71.

${ }^{27}$ Spark, 'The Curtain Blown by the Breeze' in The Collected Stories, p. 35.

${ }^{28}$ This episode is recounted in Curriculum Vitae, pp. 131-35.

${ }^{29}$ See, for example, Dougal Douglas, at the end of The Ballad of Peckham Rye (London: Macmillan, 1960), who is 'away off to Africa with the intention of selling tape-recorders to all the witch doctors' (142) and, in The Abbess of Crewe (London: Macmillan, 1974), Sister Gertrude who lives in the Congo. See also Bryan Cheyette, Diasporas of the Mind: Jewish and Postcolonial Writing and the Nightmare of History (Yale UP, 2014), chapter four.

${ }^{30}$ Spark, Curriculum Vitae, p. 119.

${ }^{31}$ Spark consistently regarded The Driver's Seat as her best work. See, for instance, Ian Rankin, 'The Deliberate Cunning of Muriel Spark', in Gavin Wallace and Randall Stevenson (eds), The Scottish Novel Since the Seventies: New Visions, Old Dreams (Edinburgh: Edinburgh University Press, 1993), pp. 43-4 and chapter three.

${ }^{32}$ Angus Wilson, 'Journey to Jerusalem', Observer (17 October, 1965), p. 28.

${ }^{33}$ Martin Stannard, Muriel Spark: The Biography (London and New York: Weidenfeld and Nicolson, 2009), chapter thirteen.

34 Muriel Spark, 'The Desegregation of Art', in the American Academy of Arts and Letters (New York: The Blashfield Foundation, 1971), p. 24.

${ }^{35}$ Spark, 'The Desegregation of Art', p. 24. 
${ }^{36}$ Stannard, Muriel Spark: The Biography, p. 370.

${ }^{37}$ The Guardian (30 September, 1970), p. 8 cited in Rankin, 'The Deliberate Cunning of Muriel Spark', p. 41.

${ }^{38}$ Quoted in Stannard, Muriel Spark: The Biography, p. 318.

${ }^{39}$ Spark, 'The Desegregation of Art', p. 23.

${ }^{40}$ Spark, 'The Desegregation of Art', p. 24.

41 Alternatively, it is possible that Spark was influenced by Mel Brooks' film The Producers (1967) which also responded to Nazism with 'helpless laughter'.

42 As Harvey Gotham states in Muriel Spark, The Only Problem (London: The Bodley Head, 1984), 'To study, to think, is to live and suffer painfully' (153). See also Spark, 'The Mystery of Job's Suffering: Jung's New Interpretation Examined', Church of England Newspaper, (15 April, 1955), p. 7, where Spark justifies retaining the epilogue to the Book of Job as it is a 'work of art'.

${ }^{43}$ Stannard, Muriel Spark: The Biography, p. 129.

${ }^{44}$ Spark, 'The First Year of My Life' in The Collected Stories, p. 301.

45 'The First Year of My Life', p. 301.

46 'The First Year of My Life', p. 303.

47 'The First Year of My Life', p. 307.

${ }^{48}$ Spark states that she 'turned my mind into a wireless set and let the characters play on my ear' in her preface to Voices at Play: Stories and Ear-Pieces (London: Macmillan, 1961), p. v.

${ }^{49}$ Stannard, Muriel Spark: The Biography, p. 65.

${ }^{50}$ Stannard, Muriel Spark: The Biography, p. xxiv.

51 Muriel Spark, Symposium (London: Constable, 1990), p. 5; Reality and Dreams (London: Constable, 1996), p. 8; and Aiding and Abetting: A Novel (London and New 
York: Viking, 2000), p. 51. I am grateful to Willy Maley who enabled me to see the connection between late and earlier Spark in these terms.

52 For Spark's 'Gentile Jewesses' see Bryan Cheyette, 'Writing against Conversion: Muriel Spark the Gentile Jewess’ in McQuillan (ed.), Theorising Muriel Spark, pp. 93112.

${ }^{53}$ Spark, 'Note to Readers', Aiding and Abetting, p. v.

54 There is a strong sense in which Aiding and Abetting is written in the ballad (rather than novelistic) tradition. Gerrard Carruthers rightly argues that the doubled and redoubled Lord Lucan is an English version of the Scottish trickster Dougal Douglas or Douglas Dougal in The Ballad of Peckham Rye. See Carruthers, "“Fully to Savour Her Position": Muriel Spark and Scottish Identity', in David Herman, Muriel Spark: TwentyFirst Century Perspectives, p. 36 and chapter one.

${ }^{55}$ Spark, Aiding and Abetting, p. 1.

${ }^{56}$ Aiding and Abetting, p. 16.

${ }^{57}$ Elizabeth Loentz, Let Me Continue to Speak the Truth: Bertha Pappenheim as Author and Activist (Cincinnati: Hebrew Union College Press, 2007).

${ }^{58}$ Aiding and Abetting, p. vi.

${ }^{59}$ Aiding and Abetting, p. 36.

${ }^{60}$ Aiding and Abetting, pp. 23-4.

${ }^{61}$ Aiding and Abetting, p. 142. This interest in the spiritual efficacy of African 'witch men' is a motif running through The Ballad of Peckham Rye and The Abbess of Crewe. Dougal, at the end of The Ballad, 'was away off to Africa with the intention of selling tape-recorders to all the witch doctors' (142); and Gertrude, throughout The Abbess, was 'in a very wild area just now, reconciling the witch doctors' rituals with a specially adapted rite of the Mass' (23). 
${ }^{62}$ Aiding and Abetting, p. 47.

${ }^{63}$ Aiding and Abetting, p. 123.

64 The 'Wolf method' stands in stark contrast to conventional Freudian psychotherapy which Spark tended to reject along the lines of Freddy Hamilton in The Mandelbaum Gate (London: Macmillan, 1965), 'No one should submit their mind to another mind' (123).

${ }^{65}$ Aiding and Abetting, p. 120.

66 ‘The Fortune-Teller' in The Collected Stories, p. 335.

${ }^{67}$ Aiding and Abetting, p. 131.

${ }^{68}$ Aiding and Abetting, p. 131 and Muriel Spark, The Mandelbaum Gate, pp. 187-190.

See also Hannah Arendt, Eichmann in Jerusalem: A Report on the Banality of Evil (London and New York: Penguin Books, 1961) and Lyndsey Stonebridge, The Judicial Imagination: Writing After Nuremberg (Edinburgh: Edinburgh University Press, 2011), chapter three, who brings Spark and Arendt together in these terms.

${ }^{69}$ Aiding and Abetting, p. 158.

${ }^{70}$ Aiding and Abetting, p. 158.

${ }^{71}$ Aiding and Abetting, p. 51 and p. 41.

${ }^{72}$ For this argument in relation to Spark's earlier novels see Cheyette, 'Writing against Conversion: Muriel Spark the Gentile Jewess', pp. 93-112.

${ }^{73}$ Aiding and Abetting, p. 48.

${ }^{74}$ Aiding and Abetting, p. 180.

${ }^{75}$ Aiding and Abetting, p. 181.

${ }^{76}$ As early as Muriel Spark's second novel Robinson (London: Macmillan, 1958) there is a parody of the transubstantiation which anticipates Aiding and Abetting. Here is January’s commentary on Robinson's way of saying 'grace': 'And when we had finished 
he gave thanks according to the form used by English Catholics, following it with that usual prayer for the faithful departed which frequently suggests to my mind that we have eaten them' (45).

${ }^{77}$ Spark, The Mandelbaum Gate, p. 32.

78 Samuel Robin Spark, 'Life with the Cambergs', The Edinburgh Star (February 1999), pp. 13-17.

${ }^{79}$ See, for instance, Alan Taylor, Appointment in Arezzo: A friendship with Muriel Spark (Edinburgh: Polygon, 2017), chapter six.

${ }^{80}$ Muriel Spark, 'A Hundred and Eleven Years Without a Chauffeur' in The Complete Short Stories (London and New York: Viking, 2001), p. 394 and pp. 394-98.

${ }^{81}$ Spark, 'A Hundred and Eleven Years Without a Chauffeur', p. 398.

${ }^{82}$ Muriel Spark, 'The Young Man who Discovered the Secret of Life' in The Complete Short Stories, p. 226 and pp. 226-28.

${ }^{83}$ Aiding and Abetting, p. 41. Spark's suspicion of an overall 'secret' unlocking the innerlife of an individual may also be one of the reasons for her contempt for conventional psychoanalysis.

${ }^{84}$ Tanya Thompson, ‘Spark Vows to Prove Ethnic Origin', The Scotsman 31 March 1998, p. 8 .

${ }^{85}$ Allan Brown, 'Will the Real Muriel Spark Stand Up?', Sunday Times 5 April 1998, p. 6; Dean Nelson, 'Spark and Son in Feud over Jewish Origins', The Observer 29 March 1998, p. 15; Thompson, 'Spark Vows to Prove Ethnic Origin', p. 8.

86 Taylor, Appointment in Arezzo, p. 127 and pp. 134-35.

${ }^{87}$ Spark, The Comforters, p. 38.

${ }^{88}$ Stannard, Muriel Spark: The Biography, pp. 518-9.

${ }^{89}$ Muriel Spark, A Far Cry from Kensington (London: Constable, 1988), p. 45. 
${ }^{90}$ Spark, Curriculum Vitae, p. 11.

${ }^{91}$ Goldie, 'Muriel Spark and the Problems of Biography', pp. 5-15.

92 Spark, 'Bang, Bang, You're Dead' in The Collected Stories, p. 85. 